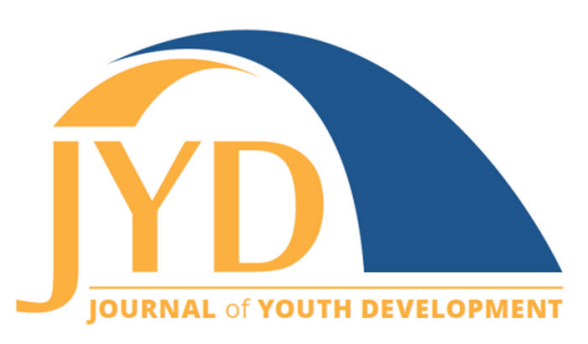

http://jyd.pitt.edu/ | Vol. 15 Issue 5 DOI 10.5195/jyd.2020.936 | ISSN 2325-4017 (online)

\title{
Youth Practitioners Can Counter Fascism: What We Know and What We Need
}

\author{
Miriam R. Arbeit \\ Department of Psychology, Suffolk University \\ marbeit@suffolk.edu \\ Sarah L. F. Burnham \\ Department of Psychology, Suffolk University \\ slburnham@su.suffolk.edu \\ Duane de Four \\ Higher Education Program, University of Massachusetts Boston \\ duane.defour001@umb.edu \\ Heather Cronk \\ Community Organizer
}

\begin{abstract}
Fascist, White nationalist, and misogynist groups are actively recruiting adolescent followers both online and in person. Youth development practitioners can play an important role in mitigating the influence of fascist ideologies on young people's behavior and reducing the proliferation of youth-perpetrated harassment and violence. In this paper, we present a theoretical integration that draws on empirical research from multiple disciplines and youth development best practices to examine how youth practitioners can counter fascist recruitment of youth. There is much that youth development researchers and practitioners already know and do, or have the capacity to learn and do, that can mitigate the threat of fascist recruitment and deter young people from developmental trajectories leading them towards harmful ideologies and actions. In order to support youth development practitioners in effectively embodying this potential, we detail 3 sets of activities: (a) immunizing youth to reduce susceptibility to fascist recruitment, (b) intervening in fascist recruitment of specific youth, and (c) counter-recruiting youth into community organizing for social justice. For each set of activities, we describe the goals of each component, propose concrete actions it may entail, and highlight existing research and best practices in the field that can be applied to this current challenge. We then propose next steps in research-practice integration to further improve relevant strategies and point to existing resources for supporting youth in resisting fascist recruitment.
\end{abstract}

Key words: youth development, violence prevention, fascism, anti-fascism, social justice

(cc) EY New articles in this journal are licensed under a Creative Commons Attribution 4.0 License. This journal is published by the University Library System, University of Pittsburgh and is cosponsored by the University of Pittsburgh Press. The Journal of Youth Development is the official peer-reviewed publication of the National Association of Extension 4-H Youth Development Professionals and the National AfterSchool Association. 


\section{Countering Fascist Recruitment of Youth}

Youth development practitioners can play a critical role in countering the complex threats posed by rising U.S. White nationalist fascism. The people who teach, nurture, and guide youth in their development have always played a vital role in shaping society; now is no different. White nationalist and misogynist hate groups across the United States are targeting White male youth online and in person to recruit them into their ranks (Dvorak, 2019; Gibson, 2019). Youth targeted for recruitment may then themselves become vectors for spreading hate through words and actions (Hankes \& Amend, 2018; Schaeffer \& Zimmermann, 2019). However, young people also have incredible resources within themselves and within their communities that, when aligned in effective ways, can keep them on positive developmental pathways even in the face of hate group recruitment attempts (Ginwright \& James, 2002; J. Lerner, et al., 2012). Youth development practitioners can be among these key sources of support in young people's lives (Griffith \& Larson, 2016). Therefore, we offer preliminary guidelines for how youth development practitioners can stop White male youth from being recruited into fascist hate groups. We developed these guidelines by combining our professional backgrounds in youth development and violence prevention with our personal experiences organizing in resistance to some of these same hate groups. We offer our perspective from our current standpoint, as we continue to adapt to new evidence in research, practice, and our ever-changing sociopolitical landscape.

In this paper, we present a theoretical integration that draws on existing empirical research across multiple disciplines, combined with youth development best practices, to guide youth practitioners to counter fascist recruitment of youth. We first describe how our own backgrounds inform the ideas presented in this paper. We next explain key concepts related to the current rise of fascism, how fascist groups may be actively targeting youth to recruit them into their violent worldviews, and how we apply anti-fascist theories within youth development frameworks. Then, we propose three bodies of work for youth development practitioners: how to immunize youth against fascist recruitment; how to intervene in fascist recruitment of youth; and how to counter-recruit youth into positive developmental pathways through community organizing for social justice. We close with reflections on next steps needed to strengthen our capacity to act.

\section{Our Backgrounds}

The first author (Mimi) and the fourth author (Heather) met in Summer 2017 when we were both supporting the anti-racist organizers of Charlottesville, Virginia in resisting escalating threats and, ultimately, lethal violence facing their community. Mimi, having moved to 


\section{Countering Fascist Recruitment of Youth}

Charlottesville the prior summer for a postdoctoral fellowship in youth development research, was a volunteer community organizer with the local chapter of Showing Up for Racial Justice (SURJ; showingupforracialjustice.org). Heather, then employed as co-director of the SURJ national network, began giving increased attention to the Charlottesville chapter, and became a mentor to Mimi and other SURJ-Charlottesville organizers. We are both White women, and the SURJ network is focused on mobilizing White people to join a multiracial movement for racial justice. As such, we collaborated with many other anti-racist organizers in Charlottesville. Our knowledge about fascism was built from the ground up, in relationships with people in Charlottesville and in communities across the country facing White nationalist and fascist threats. Our analysis was formed in countless conversations with countless people, and with each other.

Heather raised the question of counter-recruitment in Fall 2017. One way to reduce the longterm threats of rising fascism is to block fascists' attempts to grow their ranks. The theory behind counter-recruitment is that if we can recruit the same people that fascists are trying to recruit, then we can bring more people into organizing against fascism and for social justice, while directly disrupting the growth of fascist groups. Mimi drew the connection to her own background in youth development and sexual violence prevention, studying how to stop and mitigate violent cultures, particularly among young White men. To write this paper, Mimi brought in the second author (Sarah), a White female doctoral student in applied developmental psychology, and the third author (Duane), a Black male anti-violence educator who specializes in working with men and a doctoral student in education.

We focus on youth because our own experiences in Charlottesville, our observations of many growing fascist formations, and patterns in reports of recent violence suggest that fascists are specifically recruiting young people (Hankes \& Amend, 2018). No national datasets demonstrate the extent to which hate groups target youth for recruitment, nor the methods they use to do so. Some hate groups appear to target young people through connections to student groups or specific youth branches of their own organizations (Hatewatch Staff, 2017). Other groups create pathways from youth's mainstream online spaces to sites more explicit in hate and violence (Horta Ribeiro et al., 2019; Lewis, 2018). Some observers have highlighted developmental elements of this process, such as the ways in which youth seek belonging and affirmation, and the potential for cascades of alienation and antagonism as youth become increasingly caught in recruitment pathways and separated from positive communities (Hankes \& Amend, 2018; Schroeder, 2019). If recruitment happens through a developmental process, then we can use 


\section{Countering Fascist Recruitment of Youth}

developmental tools to guide youth away from it. Youth development practitioners can intervene, block, redirect, and perhaps prevent altogether the potentially devastating consequences of youth recruitment into hate-fueled movements. We find hope in the strengths of existing youth development knowledge and networks that can be leveraged to meet this challenge.

\section{Understanding Fascism and Fascist Recruitment of Youth}

Fascism may be most associated with $20^{\text {th }}$ century Europe, and, more specifically, Nazi Germany and the Holocaust. The Nazis lauded the U.S. South for its racial segregation and inequity (Grill \& Jenkins, 1992). Now, some U.S. proponents of racist violence use the fascist frameworks of Nazi Germany (Burley, 2017). With or without specific reference to Nazis, fascist frameworks and tactics are being used in the United States to pursue White nationalist genocidal agendas (Burley, 2017; Sunshine, 2017). Fascism in other countries may be used for other hierarchies of inequality, through different racial and caste systems. However, in the United States, the dominance of White male settlers over Indigenous people, Black people, and other people of color is core: codified through a complex web of ideologies, policies, and practices known as White supremacy (Alexander, 2010; Gates, 2019; Kendi, 2016). For White nationalists, the current system of racial oppression under capitalism in the United States is not unequal enough (Burley, 2017; Lyons, 2018).

Burley (2017) proposes a broad definition of fascism as a set of frameworks and tactics that promote "inequality through mythological and essentialized identity" (p. 50). Lyons (2018) uses the term far-right to refer to "forces that (a) regard human inequality as natural, inevitable, or desirable and (b) reject the legitimacy of the established political system" (p. ii). In this paper, we use both terms to highlight patterns in the desire for extreme inequality, the use of manipulative mythologies about inherent human differences, and the focus on fundamentally changing society as we know it. To read about specific movements and their differences beyond what we describe below, see sources from Political Research Associates (PRA;

politicalresearch.org) and the Southern Poverty Law Center (SPLC; splcenter.org/fighting-hate).

\section{Fascism used for White Nationalism and Male Supremacy}

Most contemporary far-right or fascist factions in the United States focus on one or more identity-based inequalities related to (a) White nationalism, which encompasses anti-Black 


\section{Countering Fascist Recruitment of Youth}

racism, anti-Indigenous colonialism, Islamophobia, and xenophobia targeting Latinx people and other immigrants of color and (b) male supremacy, targeting women, nonbinary and transgender people, and non-heterosexual (e.g., gay, lesbian, bisexual, queer) people (Burley, 2017). Anti-Semitism is an example of a fascist tactic used in service of both White nationalism and male supremacy. For example, fascists blame Jewish people for the successes of people of color, immigrants, and feminists, by weaving myths of a global Jewish conspiracy against White men (Lorber, 2019; Sunshine, 2017; Ward, 2017).

The term White supremacy emphasizes how the construction of Whiteness has been used by White people to gain and wield power over Black people, Indigenous people, and other people of color throughout the centuries (Alexander, 2010; Gates, 2019; Kendi, 2016). The term White nationalism emphasizes the fascist yearning for a White ethno-state: a nation premised on absolute power for White people over Black people, Indigenous people, and other people of color, accomplished through forced expulsion or genocide (Burley, 2017). It is this direct connection between White nationalism and genocide that makes the threat of violence corenot coincident-to fascist and far-right organizing. Several fascist groups name violence as necessary to reach their goals: some groups focus on physical fighting, some focus on arming themselves or forming militia, and some encourage individual acts of violence (Burley, 2017; Gorcenski, 2018, 2019). Some groups seek to publicly distance themselves from acts of violence committed by others on the far-right, while privately supporting or even celebrating violence as furthering the genocidal agenda of White nationalism (Burley, 2017).

Male supremacy and misogyny intersect with White supremacy and White nationalism in both U.S. history and current fascist formations. The term misogyny emphasizes the sociopolitical forces that position women as subordinate to men, restrict women to feminine and reproductive roles, and fail to protect women from violence and abuse (Combahee River Collective, 1977; Crenshaw, 1991). Male supremacy expands beyond misogyny with fascist-style conspiracy theories about women as sneaky, manipulative, and unfair to men, to justify further control and domination of, and violence against, women (DiBranco, 2017; SPLC, n.d.). Male supremacist groups and ideologies include so-called men's rights activists (MRAs), pickup artists (PUAs), "red pill" platforms, "men going their own way" (MGTOW), and "incels" (involuntary celibates), all of which also serve as pathways into White nationalism (DiBranco, 2017; Ging, 2017; Lyons, 2017; SPLC, n.d.). Male supremacy and White nationalism often intertwine; see, for example, the male supremacist backlash against the 2016 women-centered Ghostbusters remake that targeted Leslie Jones, a Black female comedian and the only woman of color among the film's 


\section{Countering Fascist Recruitment of Youth}

four leads (Blodgett \& Salter, 2018). Indeed, this avalanche of racist sexist harassment is one of many examples of the use of fascist tactics not only to harass but also to recruit (Blodgett \& Salter, 2018; DiBranco, 2017).

\section{Fascist Tactics Targeting Youth}

Because U.S. fascists are focused on White nationalism and male supremacy, the primary targets for fascist recruitment are White boys and men. Therefore, this paper addresses how youth development practitioners can support White cisgender male youth who may be directly targeted or generally impacted by fascist recruitment attempts. Whether or how fascists recruit youth of color or White female, transgender, or nonbinary youth is outside the scope of this paper. Further research may examine, for example, the ways in which White nationalist messages affect White female, transgender, or nonbinary youth, or the ways in which misogynist messages affect male youth of color.

Fascist and far-right recruitment of White male youth occurs both online and in-person. Online, youth may encounter memes, videos, and personalities that introduce them to intentionally skewed ways of thinking about themselves and others (e.g., Lewis, 2018; Mihailidis \& Viotty 2017). Far-right and fascist online communities exist in mainstream social media forums (e.g., YouTube, Facebook, Twitter, and Reddit; Graham, 2016; Lewis, 2018), gamer and other subcultural forums (e.g., Discord, 4chan, and 8chan; Mihailidis \& Viotty 2017), and on specific websites dedicated to hateful content (e.g., Stormfront; SPLC, 2015). Youth do not need to look for fascist content in order to find it. A young person may be interested in video games, politics, or how to ask someone on a date; and thus seek chat rooms, advice videos, or ways to connect with others around shared interests and then find something designed to seem reasonable and relatable (Lewis, 2018). This content that at first seems reasonable may actually be fascist propaganda and may begin, gradually, to weave a web of lies, conspiracy theories, and mythologies to recruit young people into endorsing fascist ideologies (Lewis, 2018, Horta Riberio, et al., 2019). These recruitment pathways may draw youth further into fascist worlds online, and also may draw them into in-person actions such as putting up fliers, attending rallies, or joining a fight (Gorcenski, 2019; Schaeffer \& Zimmermann, 2019; Thompson, et al., 2017).

Propaganda predates the Internet. In-person recruitment may start with a flier posted on a campus or in a neighborhood, which may use one of many manipulative tactics to obscure its White nationalist or male supremacist underpinnings (SPLC, 2017). The flier may be intended to 


\section{Countering Fascist Recruitment of Youth}

draw youth to an online forum, an in-person meeting, or an event such as a speaker or rally (Hatewatch Staff, 2017; Kruse \& Rodela, 2019; SPLC, 2017). The next steps of in-person recruitment, like online recruitment, may then entail escalating ideological manipulations (seeking to justify genocidal agendas) and leaders who exercise interpersonal influence through role modeling, peer pressure, and the guise of entertainment (Gorcenski, 2018, 2019; Schaeffer \& Zimmermann, 2019). Groups seeking to distance themselves from physical violence may have actual high school or college chapters (Hatewatch Staff, 2017; SPLC, 2017), while groups focused on street-level fighting may target economically marginalized youth outside of school contexts (e.g., Picciolini, 2017). Some youth may be recruited to form a political base, some as potential fighters or perpetrators of direct violence, and some to be groomed for leadership themselves (Gorcenski, 2019; Picciolini, 2017; Sunshine et al., 2016).

Youth recruited into fascist violence may perpetrate various forms of interpersonal harm, hate crimes, and assault (Thompson, et al., 2017; Gorcenski, 2019). In addition, White nationalist and male supremacist ideologies have been implicated in a number of recent mass shootings, notably perpetrated by young White men (Follman, 2019; Gorcenski, 2018; Hankes \& Amend, 2018). The potential for such lethal developmental pathways cannot be ignored, no matter how small.

\section{Integrating Anti-Fascist and Youth Development Theories}

Many anti-fascist efforts build on the principle of "no platform for fascism," also known as "no platforming" (Bray, 2017; Burley, 2017). No platforming means preventing any unfiltered platforms or pathways for the spread of fascist ideas. No platforming is a recognition of the inherently manipulative nature of fascist speech, from Nazi propaganda rallies and movies to today's rallies, videos, memes, and message boards, designed for the primary purpose of recruiting more people into fascist organizing (Bray, 2017; Burley, 2017).

One way of examining how "no platform" can apply to youth development practice is to use the example of cigarette advertisements. Advertisements are, by definition, designed to move the audience into action. They are designed for recruitment, not just the dissemination of ideas. Youth development communities determined that telling youth not to smoke cigarettes and instilling positive values around personal health may be necessary but not sufficient to stop youth from smoking cigarettes. Programs also provide youth explicit support to understand and resist pervasive cigarette advertisements and possible peer pressure (e.g., Kumaran et al., 2014). 


\section{Countering Fascist Recruitment of Youth}

White male youth exposed to fascist recruitment still have their own agency. It is because we believe in this agency, and thus in the potential for today's youth to recognize and see through fascist propaganda, that we want to figure out how to provide youth with the support they need to resist. It is not enough to offer alternate messages about respect and nonviolence alone. We must help youth critically digest the manipulative messages they may be exposed to, online and in person, and collaborate with them to craft positive, productive, effective options for them to pursue in response. Current core facets of positive youth development programs may prove helpful for this challenge (e.g., J. Lerner et al., 2012); but even confident, competent young people with strong character may be at risk for fascist recruitment if they lack practical preparation to respond to such targeting.

With this focus on supporting youth personal capacity to prevent fascist recruitment, we combine anti-fascist commitments to no platforming with youth development theory regarding prevention of harm (Catalano et al., 2012), intervention upon identifying signs of harm (O'Connell et al., 2009), and promotion of positive development (J. Lerner et al., 2012). For prevention, activities in which youth analyze cigarette ads (Kumaran et al., 2014) serve as a starting point for how to proactively prepare youth to encounter fascist messages. For intervention, we consider what to do when a young person displays warning signs of exposure

to fascist messages and remember the power of restorative justice and other practices that reconnect youth to positive relationships as much as possible (Riestenberg, 2008). For promotion, we explore how to support the positive development of young people and their communities by engaging youth directly in the fight against fascism and for social justice (Ginwright \& James, 2002). We draw on our practical experience with youth development programming, sexual violence prevention programming, and community organizing in resistance to U.S. White nationalist fascists. The practices we propose will need to be honed, deepened, expanded, and adapted for use in different communities, and to fit different types of youth programs with different structures and goals. We hope to help catalyze this work among vibrant networks of youth development practitioners across the country.

\section{Fighting Fascist Recruitment through Youth Development}

In this paper, we offer three sets of activities needed for a comprehensive response to fascist and far-right recruitment of White male youth towards violent ideologies and actions. We draw on youth development and public health models that differentiate among primary prevention of 


\section{Countering Fascist Recruitment of Youth}

negative outcomes, targeted intervention in negative pathways, and intentional promotion of positive outcomes. Therefore, the three components of the proposed model are

a) immunization of White male youth to reduce susceptibility to recruitment

b) intervention with youth who already display signs of recruitment

c) counter-recruitment of White male youth into work for social justice

We describe the goals of each component, propose concrete strategies to reach those goals, and highlight existing research and best practices to inform such strategies.

\section{Immunization to Reduce Youth Susceptibility to Fascist Recruitment Pathways}

The purpose of the immunization component is to reduce White male youth susceptibility to fascist recruitment efforts, thereby preventing the initiation of recruitment processes and reducing the number of youth needing intervention. These immunization practices thus represent "primary" or "universal" prevention strategies designed to address everyone in a particular population and to stop a problem before it starts (Catalano et al., 2012; Fagan \& Catalano, 2012). Primary prevention strategies have been widely used to mitigate various forms of youth violence, including physical or sexual violence (Fagan \& Catalano, 2012), dating violence (Cornelius \& Resseguie, 2007), LGBTQ+ bullying (Allen, 2014), and gangs (Lee et al., 2013).

We use the medical metaphor of immunization to highlight two elements central to primary prevention of fascist recruitment. First, analogous to vaccines, we see prevention programs as a space to monitor intentional, organized, safe exposures to toxic risk elements: to communicate directly to White male youth the content they may encounter and why and how to metabolize it. Second, we see the importance of herd immunity, a cultural shift among White male youth who share a particular social context (e.g., a school or youth program), so they reinforce positive messages amongst themselves and recognize warning signs from peers. White male youth building immunity to fascist recruitment would need to learn about the risks of fascist recruitment and develop skills and strategies to understand, avoid, and resist fascist recruitment attempts.

Table 1 provides an illustration of what immunization may entail. These recommendations are based on our own understandings of fascist recruitment of youth, and our experiences working in youth development, violence prevention, and anti-fascist community organizing. Further research and broader youth development collaborations are needed to deepen, expand, and revise this set of proposed immunization strategies. Furthermore, we do not suggest that every 


\section{Countering Fascist Recruitment of Youth}

individual youth practitioner must immediately excel in each of these competencies but rather that we need to build these skills as a professional community. White youth workers in particular may have the most proximity and access to White male youth and thus may be wellpositioned to take on the work of immunization as well as the other bodies of work we propose.

\section{Table 1. Immunization Strategies and Examples}

\begin{tabular}{|c|c|}
\hline $\begin{array}{l}\text { Practitioners should be } \\
\text { able to ... }\end{array}$ & For example ... \\
\hline $\begin{array}{l}\text { Understand and explain the } \\
\text { threats of far-right and } \\
\text { fascist recruitment of youth. }\end{array}$ & $\begin{array}{l}\text { Explain to youth the threat of far-right and fascist organizing. } \\
\text { Explain to youth online and in-person recruitment tactics, } \\
\text { including updated knowledge about recent tactical changes. }\end{array}$ \\
\hline $\begin{array}{l}\text { Use youth's personal and } \\
\text { communal values to foster } \\
\text { motivation for resisting far- } \\
\text { right and fascist recruitment. }\end{array}$ & $\begin{array}{l}\text { Foster youth empathy to resist dehumanizing messages that } \\
\text { promote violence against specific people or groups of people. } \\
\text { Foster youth motivation to avoid recruitment into far-right and } \\
\text { fascist organizing, for example, through emphasizing how these } \\
\text { tendencies are discrepant with youth or program identities, } \\
\text { values, social commitments, and/or how involvement in these } \\
\text { groups threatens youth and community safety. }\end{array}$ \\
\hline $\begin{array}{l}\text { Engage youth in skill- } \\
\text { building activities to prepare } \\
\text { for and reflect on exposure } \\
\text { to far-right and fascist } \\
\text { recruitment. }\end{array}$ & $\begin{array}{l}\text { - Build youth skills for avoiding, refusing, and safely responding } \\
\text { to fascist recruitment online and in-person. } \\
\text { - Strengthen youth critical media literacy skills, including how to } \\
\text { recognize far-right and fascist content. } \\
\text { - Workshop responses to far-right and fascist talking points youth } \\
\text { may encounter, such as about major issues or current events. } \\
\text { Initiate check-in conversations with individual youth or groups } \\
\text { of youth about whether and how they encounter online or in- } \\
\text { person recruitment. } \\
\text { Do research with youth to address questions or concerns that } \\
\text { arise. }\end{array}$ \\
\hline
\end{tabular}

The field of youth development and the related field of prevention science provide a wealth of resources that can be immediately leveraged to scaffold the above immunization activities. 


\section{Countering Fascist Recruitment of Youth}

Specifically, youth cannot be told simply not to do something; rather, they must be provided with motivation, skills, and support for avoiding the behavior in question (Prochaska et al., 2015).

One area of skill building essential for immunization activities is media literacy. Youth need to understand both mainstream and social media, digital and otherwise, in order to understand how media is used in fascist recruitment. General best practices in building youth media literacy (e.g., Cope \& Flanagan, 2013; Mihailidis \& Thevenin, 2013) should be supplemented with specific skills relevant to resisting fascist recruitment: how to identify far-right and fascist media content (Sutton \& Wright, 2009), how to critique racist and sexist media messages (Kellner \& Share, 2007), how to differentiate between trustworthy and suspect media sources (Stanford History Education Group, 2016), how to manage the potential emotional confusions of digital selfhood and digital relationships (Chen, 2016; Gleason et al., 2017), and how to recognize particular patterns of fascist or far-right manipulation (Gibson, 2019; Van Valkenburgh, 2018). Creating one's own media content is an important part of media literacy skill building (Koc \& Barut, 2016), so immunization activities may include creating media content that helps warn other youth about the risks of fascist recruitment and/or creating content that affirms equityfocused values. Youth need support not only to critically consume online media but also to actively engage with and contribute to digital political communities (Leighninger, 2014, 2018).

To be critical consumers and producers of media, and to debunk fascist and far-right messages, youth will need opportunities to develop their own analysis of the multiple complex sources of harm in society. Male youth need support in compassionately critiquing unrealistic, unfair expectations of toxic masculinity in ways that align them with (rather than push them away from) feminism, women's rights, and efforts to end sexual violence (Flood, 2011; Messner, 2016). White male youth in particular need support in compassionately critiquing their own White privilege without sinking into White guilt, and in affirming a White racial identity invested in equity and solidarity rather than further disparity (Helms, 1995). These identity development processes for building immunity also sow the seeds for positive motivations towards social change.

Research on motivation suggests that approach motives-being motivated to approach a positive outcome-may be associated with greater well-being than avoidance motives-being motivated to avoid a negative outcome (Gable, 2006; Gable \& Impett, 2012). Although prevention seems founded on avoidance motives (to avoid becoming a perpetrator of fascist 


\section{Countering Fascist Recruitment of Youth}

violence, or to avoid ostracization from a peer group for which fascism falls outside shared values), there may be ways to foster approach motives as well. Approach motives can come from opportunities for youth to internalize prosocial norms (Smischney et al., 2018), strengthen ethical decision-making (Saleh et al., 2017), access positive ways to meet pressing needs (Lee et al., 2013), and develop empathy for people different from themselves (Riley, 2019). Related to motivation is persistence, which can grow from framing mistakes as part of a learning process that takes time and effort (growth mindset), and from relational contexts that support youth in risk-taking, experimentation, and teamwork (Ryoo \& Kekelis, 2018). Motivation and persistence can help youth open themselves to these new, complex, and at times overwhelming challenges.

\section{Intervention to Divert Youth from Fascist Recruitment Pathways}

The purpose of the intervention component is to divert youth who have already initiated fascist or far-right recruitment trajectories, which corresponds to public health frameworks of secondary prevention or indicated intervention (O'Connell et al., 2009). We focus on youth who exhibit warning signs of possible interest or early involvement in fascist or far-right ideologies. This intervention work is distinct from groups like Life After Hate (lifeafterhate.org) that work with people trying to leave active membership in fascist organizations who may face backlash from those organizations (including threats of violence). The earlier aspects of fascist or farright recruitment trajectories we focus on here include online engagement such as following fascist accounts, sharing memes, or repeating conspiracy theories; in-person contact such as attending rallies, lectures, or meetings with individual organizers; and actions such as reiterating fascist talking points, contributing to hate-based harassment, or recruiting others. Table 2 illustrates possible intervention strategies. Again, these are based on our own understandings and experiences and further research is needed to hone these strategies.

The field of youth development provides a wealth of resources that can be immediately leveraged to scaffold the activities in Table 2. Here we highlight how to understand a young person's individual needs, how to assess youth influences, and how to address harm youth may cause. 
Table 2. Intervention Strategies and Examples

\begin{tabular}{|c|c|}
\hline $\begin{array}{l}\text { Practitioners should be } \\
\text { able to ... }\end{array}$ & For example ... \\
\hline $\begin{array}{l}\text { Identify youth who may be } \\
\text { in need of intervention. }\end{array}$ & $\begin{array}{l}\text { - Identify red flags and other warning signs of fascist recruitment } \\
\text { trajectories. } \\
\text { Identify the individual factors that render a particular young } \\
\text { person susceptible to fascist recruitment, such as social } \\
\text { dominance beliefs (e.g., male dominance, White supremacy), } \\
\text { unresolved political anger, feelings of disenfranchisement, } \\
\text { shame related to personal identity and search for belonging, or } \\
\text { prejudice (e.g., sexism, racism, xenophobia). } \\
\text { Analyze the function of different recruitment tactics youth } \\
\text { encounter, such as online versus in-person tactics, or use of } \\
\text { White supremacist versus misogynist ideologies. }\end{array}$ \\
\hline $\begin{array}{l}\text { Respond directly to } \\
\text { comments or behaviors that } \\
\text { indicate far-right or fascist } \\
\text { influence. }\end{array}$ & $\begin{array}{l}\text { Address any warning signs through direct conversation with } \\
\text { youth involved. Ignoring a warning sign implicitly gives } \\
\text { permission for youth to further entrench themselves in fascist } \\
\text { ideas and for the ideas to further spread among a peer group. } \\
\text { Avoid using punitive shaming measures; young people's shame } \\
\text { can be manipulated by fascists as fodder for further } \\
\text { recruitment. } \\
\text { Work with colleagues to develop a plan of action for responding } \\
\text { to cases in which fascist-influenced behavior manifests directly } \\
\text { within program contexts, such as if youth repeat fascist talking } \\
\text { points or contribute to hate-based harassment. } \\
\text { Support the young people who may be harmed when their } \\
\text { peers exhibit fascist-influenced behavior. }\end{array}$ \\
\hline $\begin{array}{l}\text { Provide targeted support to } \\
\text { youth who display red flags } \\
\text { or warning signs. }\end{array}$ & $\begin{array}{l}\text { Initiate conversations with recruited youth that strengthen the } \\
\text { youth-adult relationship and provide individualized support as } \\
\text { needed. } \\
\text { Divert youth from fascist recruitment trajectories by connecting } \\
\text { them to positive alternative trajectories (see the following } \\
\text { section on counter-recruitment). }\end{array}$ \\
\hline
\end{tabular}




\section{Countering Fascist Recruitment of Youth}

The key to intervening to divert youth from fascist and far-right recruitment pathways is to foster interpersonal connection between youth and adults who can redirect them, using youth practitioners' expertise in building close, connected youth-adult relationships (Griffith \& Larson, 2016). It is important, to the extent possible, to avoid shaming the young person in a way that drives disconnection. Intervening in recruitment pathways in personalized, non-shaming ways may require assessing youth political reasoning (Flanagan, 2013), risk for aggression (Cohen \& Prinstein, 2006), authoritarian or social dominance beliefs (Cargile, 2017; Duriez \& Soenens, 2009; Duriez et al., 2007), and endorsement of stereotypes and prejudice (Bigler \& Liben, 2006). Assessing these factors may help adults understand individual differences in youth susceptibility to recruitment.

In addition to understanding a young person's specific personalities, beliefs, and reasoning, youth workers will need to understand the many layers of social influences shaping their behavior (Huang et al., 2014; Prinstein \& Dodge, 2008). The term "parasocial relationships" refers to the ways in which youth can interact and even emotionally bond with online "influencers" on social media platforms (Gleason et al., 2017). These relationships are parasocial due to their one-directional nature: youth may experience the relationship intimately while the influencer does not know or care about them in return (Gleason et al., 2017). Influencers can, as the term suggests, shape youth behavior, such as by giving permission or even explicit instructions to join an online pile-on of hate-fueled harassment (e.g., Blodgett \& Salter, 2018; Jeong, 2018). Although many functions of parasocial relationships are unique to the current digital landscape, the function of a distant "influencer" may also be relevant to inperson recruitment dynamics. Identifying the key influences on a young person's recruitment trajectory, and what needs and interests may drive a young person towards these influences, may help in identifying next steps towards restoration.

The fascist recruitment pipeline is primed to pull in White male youth who experience rejectionfocused punishment for sharing fascist content or repeating fascist talking points (Gibson, 2019). Restorative justice or similar accountability approaches build from a foundation of community belonging and thus can pull youth further into a positive community even while responding directly to any indication of fascist or far-right influences on behavior. These approaches seek to teach youth about the ramifications of their behavior without alienating or exiling them from communities such as youth programs (Riestenberg, 2008). Furthermore, it is important that even seemingly small acts of bigotry or violence be addressed because these can escalate in severity (Follman, 2019; Juodis et al., 2014). 


\section{Countering Fascist Recruitment of Youth}

We would be remiss to forget the young people who themselves are harmed when their White male peers, already enmeshed in recruitment pathways, make comments or take actions in hateful, discriminatory, or threatening ways. Responding to incidents of harm must promote positive developmental pathways both for youth perpetrating harm, as discussed above, and for youth who have been hurt. The person hurt may benefit from community support through acknowledgement of the harm done, affirmation of inclusive community values, and opportunities to reconnect with caring peers and adults. The person hurt may also need mental health care, academic accommodations, or other material resources. Positive curricular and program representation of young people's marginalized identities, and program policies that make it clear that targeting marginalized people will not be accepted, support resilience among marginalized youth (Allen, 2014). Another significant step towards healing harm is to build a better world, in solidarity with those directly impacted by current social structures, which is part of the process of counter-recruitment described in the next section.

\section{Counter-Recruitment into Community Organizing for Social Justice}

The purpose of counter-recruitment is to bring youth into social justice organizing and away from fascist recruitment pathways. Social justice organizing involves processes through which communities can undo cultures and systems of hierarchy, oppression, and division that feed the current rise of fascism, while building alternative cultures and systems of equity, solidarity, and interdependence (Adams \& Bell, 2016; Ginwright \& James, 2002). Youth development and public health promotion corroborate that prevention in itself is not enough to guide youth along positive developmental pathways; youth need intentional support to develop positive strengths (Catalano et al., 2002; Durlak, 2000; R. Lerner, 2001). The concept of counter-recruitment shifts from individualized promotion towards community-based promotion, engaging young people in promoting their own thriving through promoting communal thriving (Ginwright \& James, 2002). Communal thriving promotes individual thriving and vice versa (J. Lerner et al., 2012). White male youth susceptibility to fascist recruitment is heightened by the adolescent search for belonging and in-group identification (Brewer, 1999; Yang et al., 2013) and by material hardship (Sunshine et al., 2016). Promotion of individual strengths would be inadequate to counter fascist recruitment without emphasis on the social, political, and economic conditions of youth lives.

For example, over the past half-century, political conservatives intensified their efforts to build and consolidate power in Southern and rural predominately-White communities. They hollowed out civic infrastructure under the guise of smaller government and lower taxes; then, as schools crumbled into disrepair, libraries and hospitals closed their doors, and functions of local 


\section{Countering Fascist Recruitment of Youth}

government like water and utilities were privatized, right-wing militia groups moved into the civic vacuum to provide direct services in lieu of local government (Zimmer et al., 2018). These conditions position economically struggling youth to see right-wing militia as heroes and believe their anti-government conspiracy theories (Sunshine et al., 2016). Fascist recruitment is not only happening in rural or Southern communities; this example is one illustration of what we mean by attending to underlying conditions.

We propose counter-recruitment to engage youth in community organizing against fascism; against societal foundations of U.S. fascism such as racism, sexism, xenophobia, and transphobia; and towards the goal of shifting material conditions so as to render the wedges of race and class ineffective (Burley, 2017). Counter-recruitment can draw on Freirian methods that combine critical reflection on harmful systems with action to create helpful, healing systems (Freire, 1970; Ginwright, 2016; Watts et al., 2011). We present this section to illustrate what counter-recruitment might look like, and to encourage imaginations among youth programs that may be positioned to explore it. We see counter-recruitment as a specific body of work that is important for some programs to engage in, within the broader youth development field. We do not believe that any or even most youth programs need to be doing this work. That said, some practitioners may feel drawn to pursue certain pieces of counter-recruitment, perhaps in partnership with local adult or young adult social justice community organizers, particularly when threats of fascism are acutely felt in local or national news. Counterrecruitment does not need to be labeled or presented as such, given that it fits within broader social justice efforts. Table 3 illustrates our recommendations for how to begin developing counter-recruitment strategies to be adapted and honed in youth development programs positioned to take on this work.

The fields of youth and community organizing provide a plethora of resources that can be immediately leveraged for counter-recruitment efforts, ranging from how to design campaigns to how to reinforce social justice commitments. Here we highlight both intergenerational and youth-centered organizing practices and draw connections to literature on youth civic engagement. 
Table 3. Counter-Recruitment Strategies and Examples

\begin{tabular}{|c|c|}
\hline $\begin{array}{l}\text { Practitioners should be } \\
\text { able to ... }\end{array}$ & For example . . . \\
\hline $\begin{array}{l}\text { Use social justice } \\
\text { community organizing } \\
\text { strategies to engage youth } \\
\text { in collective action. }\end{array}$ & $\begin{array}{l}\text { - Ask youth what kind of world they want to live in, and engage in } \\
\text { lengthy meaning-making conversations in which youth can } \\
\text { examine and expand their yearnings. } \\
\text { Engage youth in creative community organizing campaigns } \\
\text { characterized by anti-fascism, anti-racism, anti-sexism, and/or } \\
\text { social justice worldbuilding. Find campaigns that affect youth's } \\
\text { own lives and the lives of others in their communities, so youth } \\
\text { associate social justice organizing with concrete positive impact. } \\
\text { Have youth create and disseminate their own media products as } \\
\text { part of social justice campaigns, to strengthen youth media } \\
\text { literacy and thus reinforce immunization. }\end{array}$ \\
\hline $\begin{array}{l}\text { Support youth in the } \\
\text { complexities and } \\
\text { contradictions often } \\
\text { encountered in social } \\
\text { justice organizing. }\end{array}$ & $\begin{array}{l}\text { - Facilitate critical consciousness among youth with socially } \\
\text { dominant identities (e.g., White male youth) while managing } \\
\text { guilt, shame, or fragility that may arise in relation to these } \\
\text { identities. } \\
\text { - Encourage White male youth leadership without reducing, } \\
\text { discouraging, or undermining the leadership of youth who are } \\
\text { not White and/or not male. Foster White male youth belonging } \\
\text { without wavering in anti-oppression commitments. } \\
\text { Support youth in establishing and maintaining community norms } \\
\text { against bigotry, racism, sexism, xenophobia, transphobia, } \\
\text { homophobia, and other behavior that reinforces fascist } \\
\text { ideologies. } \\
\text { Support youth in establishing and implementing community } \\
\text { processes of accountability so that someone who displays } \\
\text { warning signs of fascist recruitment can be supported in } \\
\text { rectifying harm while returning to the collective pursuit of social } \\
\text { justice. }\end{array}$ \\
\hline
\end{tabular}




\section{Countering Fascist Recruitment of Youth}

Table 3. (continued)

\begin{tabular}{|l|l|}
\hline $\begin{array}{l}\text { Practitioners should be } \\
\text { able to ... }\end{array}$ & For example ... \\
\hline $\begin{array}{l}\text { Provide youth with social } \\
\text { justice role models who } \\
\text { resist fascism. }\end{array}$ & $\begin{array}{l}\text { Teach the histories of those who have resisted fascism, against } \\
\text { all odds. Increase the presence of anti-fascist symbols and } \\
\text { artwork in youth spaces and talk with youth about the stories } \\
\text { represented. Encourage youth to ask questions about these } \\
\text { histories in order to connect with anti-fascist role models. } \\
\text { Introduce youth to trusted local community members currently } \\
\text { working to resist fascism, by inviting them to speak or bringing } \\
\text { youth to a safe and accessible anti-fascist event. }\end{array}$ \\
\hline
\end{tabular}

Through collaborating towards a community organizing campaign goal, youth build an experiential analysis of their own identities in relation to systems of power inequity (Ginwright \& James, 2002). An analysis of inequality and a resilient personal identity developed through collective, connected, relational experiences of striving for equity are direct inoculations against the ways fascist and far-right ideologies valorize identity-based inequalities. The experience of connectedness is key: Community organizing campaigns are most effective and most meaningful when all involved (youth and adults) are building authentic, trusting relationships with each other (Chávez et al., 2007). Through such relationships, youth and adults can share values, hopes, goals, knowledge, skills, and cultural insights and find concrete ways to take care of each other. For example, in-person gatherings like Southern Movement Assemblies (SouthtoSouth.org) engage in the kind of anti-oppression world-building that can be a powerful alternative to fascist recruitment. These assemblies actively resist the isolation that can fuel susceptibility to fascism and ask participants to commit to action in solidarity with others across the region. Community-driven initiatives like these welcome young people and promote intergenerational relationship-building through collective efforts to change the material conditions of oppression.

The legacy of youth-specific community organizing also models counter-recruitment against fascism. There are ample examples from $20^{\text {th }}$ century Europe of counter-recruitment efforts through youth subcultures such as punk rock and football scenes (Bray, 2017; Jones, 2017), which are reflected in $21^{\text {st }}$ century efforts in the United States to counter-recruit a new generation of young music and sports fans (e.g., Maza, 2017; Murphy, 2019). College student 


\section{Countering Fascist Recruitment of Youth}

organizers use anti-fascist education and community-building to respond to fascist targeting and prevent fascists from using their schools as ground for recruitment (e.g., at the University of Virginia, @UVAstudentsUNITED on Facebook; at Michigan State University, @StopSpencerMSU on Facebook). The Campus Antifascist Network also supports students in preempting and resisting fascist recruitment (Burley, 2018a). Youth-specific community organizing can draw on related research such as social justice youth development (Ginwright \& James, 2002) and the development of critical consciousness (Watts et al., 2011).

Youth development practitioners' expertise in facilitating youth civic engagement (e.g., Jain et al., 2019) and civic leadership (e.g., Nicotera \& Bassett, 2015) is particularly relevant to the counter-recruitment activities we propose. Youth community organizing for social justice can be understood as a form of civic engagement termed "participatory politics," which Kahne and colleagues (2015) define as "interactive, peer-based acts through which individuals and groups seek to exert both voice and influence on issues of public concern" (p. 3). Although digital media provide unique opportunities for youth to engage in participatory politics, the framework includes in-person activities as well (Kahne et al., 2015). Facilitating youth civic engagement and participatory politics must be combined with an explicit focus on anti-fascist, antioppression, and social justice content in order to effectively counter fascist recruitment.

Further work is needed to develop methods for counter-recruiting White male youth into social justice organizing. Specific theorizing, research, and program design can examine how to attend to the political needs of White male youth without reifying potentially toxic elements of Whiteness and maleness, and without causing further harm to non-White and/or non-male youth who are targets of fascist ire. We call for deep work on these questions even as we remain humble to the many fault lines that projects focusing on Whiteness and White individuals often breach (Curry-Stevens, 2010).

\section{Next Steps in Anti-Fascist Research-Practice Integration}

In the sections above, we proposed that youth development practitioners should understand, teach about, and recognize the ways in which White nationalist and male supremacist fascist groups target youth for recruitment into their ranks. But we did not describe specific warning signs for youth practitioners to know about in order to do these things. In this section, we suggest possible warning signs, highlight the limitations of existing knowledge, and propose next steps in anti-fascist research-practice integration to fill current gaps. 


\section{Countering Fascist Recruitment of Youth}

Warning signs that a young person may be exposed to fascist recruitment include wearing, drawing, or promoting hate symbols (see adl.org/hate-symbols), and following on social media, engaging with or promoting hate groups (see splcenter.org/fighting-hate). Warning signs also include repetition of fascist talking points, such as victimization narratives or conspiracy theories. Victimization narratives distort reality with claims that a socially dominant group (e.g., White men) is discriminated against, stigmatized, threatened, or harmed by current social forces (Berbrier, 2000). Corresponding tactics include co-opting social justice movements to recenter dominant identities (Burley, 2017), as seen in rallies for "White Lives Matter" (Hand, 2017), "Him Too" (Burley, 2018b), and "Straight Pride" (Quinlan, 2019). Some victimhood claims blame multiculturalism, political correctness, or liberals in general (Berbrier, 2000; Sunshine, 2017). Others cast blame through conspiracy theories: for example, accusations of a feminist conspiracy to revoke men's rights and refuse men access to sex (DiBranco, 2017); or myths of a Jewish conspiracy to use Black people or immigrants of color to take power and control away from White people (Lorber, 2019; Sunshine, 2017; Ward, 2017).

Although fascist patterns of manipulative victimization narratives and conspiracy theories are likely to persist, any specific examples could be outdated by the time this article is read. To fill this gap in knowledge about specific warning signs, we need a way to facilitate trusted communication among researchers and practitioners that can transpire in days or weeks-not years. Such time-sensitive collaboration is needed to better understand fascist recruitment of youth, to support youth resistance to recruitment, and to support youth practitioners in responding to what they see.

- To better understand fascist recruitment of youth, researchers and practitioners could work together to document the most common and threatening recruitment tactics; analyze the developmental implications of tactical adaptations as they are occurring; and make connections between fascist recruitment tactics and the comments, behaviors, and other challenges practitioners encounter in their work with White male youth.

- To better support youth resistance to fascist recruitment, researchers and practitioners could work together to identify appealing and effective ways for White male youth to refuse and respond to fascist recruitment tactics; adapt responses as new fascist talking points arise; and create tools for adults to talk with youth about fascist and far-right messages they may be exposed to.

- To better support youth practitioners in responding to warning signs of fascist recruitment, researchers and practitioners could work together to hone 


\section{Countering Fascist Recruitment of Youth}

restorative program policies to address harm done, care for marginalized youth who may have been harmed, and divert recruited youth towards positive development.

The key feature of the anti-fascist research-practice integration we suggest here is its timeliness. We envision a network that can gather information, conduct analyses, and disseminate findings within days or weeks, as needed. Collaborators would build trust with each other to share insights and check each other's work, so information disseminated could be as rigorous as possible within a tight timeframe. Youth, too, could make invaluable contributions in collaboration with researchers and practitioners, through their reflections on recruitment they encounter, and their visions for how to support each other in resistance.

\section{Discussion}

This paper is a call to action to the youth development community to pursue a multifaceted approach to stop fascist and far-right recruitment of White male youth. Youth development practitioners are well positioned to mitigate the influence of fascist ideologies on White male youth and reduce the proliferation of fascist-influenced youth violence. In order to support youth development practitioners in effectively embodying this role, we have detailed three sets of activities: (a) immunizing all White male youth to reduce susceptibility to fascist recruitment, (b) intervening in fascist recruitment of specific youth, and (c) counter-recruiting White male youth into social justice community organizing.

We recognize several limitations imposed by the brevity of the current presentation of this model. Space limitations prevented a comprehensive explanation of current fascist recruitment pathways, which is needed for youth practitioners to more fully understand the threats that young people need help resisting. In addition, there is more that could go into explaining each

of the specific youth development strategies proposed. Future work must detail and disseminate such strategies. Furthermore, such strategies will be most effective when connected to a broader fight against fascism that addresses the breeding ground for fascist inequalities built into the foundation of our society through White supremacy, patriarchy, capitalism, and colonialism (Burley, 2017).

Even given these limitations, this model provides a foundation for youth development practitioners to begin or continue the multifaceted work of countering fascist recruitment of youth. The strengths of the model are in outlining the three distinct, specific bodies of work, 


\section{Countering Fascist Recruitment of Youth}

and in the ways in which these bodies of work draw on expertise from multiple disciplines, including youth development as well as psychology, public health, and community organizing. In presenting this multidisciplinary framework, we assert simultaneously that we do know enough to start acting immediately, and that there is much more we need to figure out as promptly as possible. Future work is needed to develop tool kits, professional development, and other resources to support youth practitioners willing to take on the challenge of countering fascist recruitment.

These resources can delve deeper into effective implementation of the strategies in Tables 1-3 and potential problems for practitioners to avoid. In particular, we suggest future work take a race-explicit approach to support White youth workers in the deep personal work of anti-racist identity development and in modeling and facilitating anti-racist developmental processes with White youth (Harbin et al., 2019). It is not the responsibility of people of color to take on the emotional burdens of teaching White people to value racial equity (Harbin et al., 2019). White youth workers may be most proximal to youth behavior indicating fascist or far-right influence; may have more social power and emotional capacity with which to hold White youth accountable for causing harm; and may be well-positioned to talk with youth about Whiteness, identity, and community. See Table 4 for examples of existing resources for supporting youth in resisting fascist recruitment.

We invite youth development practitioners, researchers, and young people themselves to join us in research-practice integration and collaboration as we seek innovative approaches to fighting fascism and pursuing social justice. Together, guided by the wisdom of both experience and empiricism, we can and must adapt to take on new challenges. Together, we can stop fascist recruiters from preying on our youth, and we can stop youth from perpetrating harm against others and against our society. Instead, we can welcome all youth into the fight against fascism and for social justice. 
Table 4. Examples of Existing Resources for Supporting Youth in Resisting Fascist Recruitment

\begin{tabular}{|c|c|c|}
\hline Name & Source & Description and URL \\
\hline $\begin{array}{l}\text { Confronting } \\
\text { White } \\
\text { Nationalism in } \\
\text { Schools: A } \\
\text { Toolkit }\end{array}$ & $\begin{array}{l}\text { Western States } \\
\text { Center }\end{array}$ & $\begin{array}{l}\text { A 50-page document with suggestions for proactive and reactive } \\
\text { strategies that students, teachers, parents, and school } \\
\text { administrators can use to combat White nationalism. Uses } \\
\text { specific examples of White nationalist symbols, talking points, } \\
\text { and signs to watch out for. } \\
\underline{\text { https://www.westernstatescenter.org/schools }}\end{array}$ \\
\hline $\begin{array}{l}\text { Explainer: White } \\
\text { Nationalism }\end{array}$ & $\begin{array}{l}\text { Facing History } \\
\text { and Ourselves }\end{array}$ & $\begin{array}{l}\text { This 4-page document defines seven relevant vocabulary terms } \\
\text { and provides an explanation of and responses to five core White } \\
\text { nationalist beliefs. Includes a brief explanation of how White } \\
\text { nationalists use violence, humor, media, sarcasm, victim } \\
\text { narratives, targeted recruitment, and other strategies to spread } \\
\text { their ideas to youth. } \\
\text { https://www.facinghistory.org/sites/default/files/Facing History } \\
\text { Explainer White Nationalism Handout.pdf }\end{array}$ \\
\hline $\begin{array}{l}4 \text { Steps to Help } \\
\text { Kids Push Back } \\
\text { Against White } \\
\text { Nationalism }\end{array}$ & $\begin{array}{l}\text { Nora Flanagan } \\
\text { and Christian } \\
\text { Picciolini, with } \\
\text { EmbraceRace }\end{array}$ & $\begin{array}{l}\text { A 2-page document that outlines what parents can do to } \\
\text { understand the issue, speak with children, and speak with } \\
\text { schools. Contains links to recommended resources for further } \\
\text { reading. https://www.embracerace.org/assets/4-steps-for- } \\
\text { supporting-kids-against-white-nationalism.pdf }\end{array}$ \\
\hline
\end{tabular}

\section{Acknowledgements}

Thank you to Lisette DeSouza, Emily Gorcenski, Elise Harris Wilkerson, and our anonymous reviewers for feedback on previous versions of this manuscript. Thank you also to all who fight fascism in many ways every day.

\section{References}

Adams, M. \& Bell, L. A. (Eds., with Goodman, D. J., \& Joshi, K. Y.). (2016). Teaching for diversity and social justice. Routledge.

Alexander, M. (2010). The new Jim Crow: Mass incarceration in the age of colorblindness. The New Press. 
Allen, K. (2014). Addressing the issue: Bullying and LGBTQ youth. Journal of Youth Development, 9(3), 40-46. https://doi.org/10.5195/jyd.2014.49

Berbrier, M. (2000). The victim ideology of White supremacists and White separatists in the United States. Sociological Focus, 33(2), 175-191.

Bigler, R. S., \& Liben, L. S. (2006). A developmental intergroup theory of social stereotypes and prejudice. Advances in Child Development and Behavior, 34, 39-89. https://doi.org/10.1016/s0065-2407(06)80004-2

Blodgett, B. \& Salter, A. (2018). Ghostbusters is for boys: Understanding geek masculinity's role in the alt-right. Communication Culture \& Critique, 11, 133-146. https://doi.org/10.1093/ccc/tcx003

Bray, M. (2017). Antifa: The anti-fascist handbook. Melville House.

Brewer, M. B. (1999). The psychology of prejudice: Ingroup love and outgroup hate? Journal of Social Issues, 55(3), 429-444. https://doi.org/10.1111/0022-4537.00126

Burley, S. (2017). Fascism today: What it is and how to end it. AK Press.

Burley, S. (2018a, February 22). Anti-fascist organizing explodes on US college campuses. Waging Nonviolence. https://wagingnonviolence.org/2018/02/antifascist-organizing-explodes-collegecampuses

Burley, S. (2018b, November 21). Survivors confront far right's \#HimToo campaign in Portland. Truthout. https://truthout.org/articles/survivors-confront-far-rights-himtoo-campaign-in-portland/

Cargile, A. C. (2017). Social dominance orientation: A root of resistance to intercultural dialogue? International Journal of Intercultural Relations, 61, 40-53. https://doi.org/10.1016/j.ijintrel.2017.09.003

Catalano, R. F., Fagan, A. A., Gavin, L. E., Greenberg, M. T., Irwin, C. E., Ross, D. A., \& Shek, D. T. (2012). Worldwide application of prevention science in adolescent health. The Lancet, 379(9826), 1653-1664. https://doi.org/10.1016/s0140-6736(12)60238-4

Chávez, V., Minkler, M., Wallerstein, N., \& Spencer, M. S. (2007). Community organizing for health and social justice. In L. Cohen, S. Chehimi, \& V. Chávez (Eds.), Prevention is primary: Strategies for community well-being. Wiley.

Chen, C.-P. (2016). Forming digital self and parasocial relationships on YouTube. Journal of Consumer Culture, 16(1), 232-254. https://doi.org/10.1177/1469540514521081

Cohen, G. L., \& Prinstein, M. J. (2006). Peer contagion of aggression and health risk behavior among adolescent males: An experimental investigation of effects on public conduct and private attitudes. Child Development, 774), 967-983. https://doi.org/10.1111/j.1467-8624.2006.00913.x

Combahee River Collective. (1977). Combahee River Collective statement: Black feminist organizing in the seventies and eighties. (Freedom Organizing Series). Combahee River Collective. https://combaheerivercollective.weebly.com/the-combahee-river-collective-statement.html 
Journal of Youth Development | http://jyd.pitt.edu/ | Vol. 15 Issue 5 DOI 10.5195/jyd.2020.936 Countering Fascist Recruitment of Youth

Cope, J., \& Flanagan, R. (2013). Information literacy in the study of American politics: Using new media to teach information literacy in the political science classroom. Behavioral \& Social Sciences Librarian, 32(1), 3-23. https://doi.org/10.1080/01639269.2013.750198

Cornelius, T. L., \& Resseguie, N. (2007). Primary and secondary prevention programs for dating violence: A review of the literature. Aggression and Violent Behavior, 12(3), 364-375. https://doi.org/10.1016/j.avb.2006.09.006

Crenshaw, K. (1991). Mapping the margins: Intersectionality, identity politics, and violence against Women of Color. Stanford Law Review, 43(6), 1241-1299.

Curry-Stevens, A. (2010). Journeying toward humility: Complexities in advancing pedagogy for the privileged. Reflections: Narratives of Professional Helping, 16(1), 61-72.

DiBranco, A. (Winter 2017). Mobilizing misogyny. (The Public Eye). Political Research Associates. https://www.politicalresearch.org/2017/03/08/mobilizing-misogyny

Duriez, B., \& Soenens, B. (2009). The intergenerational transmission of racism: The role of right-wing authoritarianism and social dominance orientation. Journal of Research in Personality, 43, 906909.

Duriez, B., Soenens, B., \& Vansteenkiste, M. (2007). In search of the antecedents of adolescent authoritarianism: The relative contribution of parental goal promotion and parenting style dimensions. European Journal of Personality, 21(4), 507-527. https://doi.org/10.1002/per.623

Durlak, J. A. (2000). Health promotion as a strategy in primary prevention. In D. Cicchetti, J. Rappaport, I. Sandler, \& R. P. Weissberg (Eds.), The Promotion of Wellness in Children and Adolescents (pp. 221-241). Child Welfare League of America.

Dvorak, P. (2019, August 15). White supremacists are recruiting white teens online. Parents must stop them. The Washington Post. https://www.washingtonpost.com/local/white-supremacists-arerecruiting-white-teens-online-parents-must-stop-them/2019/08/15/5169c192-bf69-11e9-b87363ace636af08 story.html

Fagan, A. A., \& Catalano, R. F. (2012). What works in youth violence prevention: A review of the literature. Research on Social Work Practice, 23(2), 141-156.

https://doi.org/10.1177/1049731512465899

Flanagan, C. A. (2013). Teenage citizens: The political theories of the young. Harvard University Press.

Flood, M. (2011). Involving men in efforts to end violence against women. Men and masculinities, 14(3), 358-377. https://doi.org/10.1177/1097184x10363995

Follman, M. (2019, June). Armed and misogynist: How toxic masculinity fuels mass shootings. Mother Jones. https://www.motherjones.com/crime-justice/2019/06/domestic-violence-misogyny-incelsmass-shootings/

Freire, P. (1970). Pedagogy of the oppressed. Continuum. 
Journal of Youth Development | http://jyd.pitt.edu/ | Vol. 15 Issue 5 DOI 10.5195/jyd.2020.936 Countering Fascist Recruitment of Youth

Gable, S. L. (2006). Approach and avoidance: Social motives and goals. Journal of Personality, 74(1), 175-222. https://doi.org/10.1111/j.1467-6494.2005.00373.x

Gable, S. L., \& Impett, E. A. (2012). Approach and avoidance motives and close relationships. Social and Personality Psychology Compass, 6(1), 95-108. https://doi.org/10.1111/j.17519004.2011.00405.x

Gates, H. L. (2019). Stony the Road: Reconstruction, white supremacy, and the rise of Jim Crow. Penguin Books.

Gibson, C. (2019, September 17). 'Do you have white teenage sons? Listen up.' How white supremacists are recruiting boys online. The Washington Post. https://www.washingtonpost.com/lifestyle/onparenting/do-you-have-white-teenage-sons-listen-up-how-white-supremacists-are-recruitingboys-online/2019/09/17/f081e806-d3d5-11e9-9343-40db57cf6abd story.html

Ging, D. (2017). Alphas, betas, and incels: Theorizing masculinities of the manosphere. Men and Masculinities, 1-20. https://doi.org/10.1177/1097184X17706401

Ginwright, S. (2016). Hope and healing in urban education: How urban activists and teachers are reclaiming matters of the heart. Routledge.

Ginwright, S., \& James, T. (2002). From assets to agents of change: Social justice, organizing, and youth development. New Directions for Youth Development, 2002(96), 27-46.

Gleason, T. R., Theran, S. A., \& Newberg, E. M. (2017). Parasocial interactions and relationships in early adolescence. Frontiers in Psychology, 8. https://doi.org/10.3389/fpsyg.2017.00255

Gorcenski, E. (2018, October 28). The Pittsburgh shooting proves Trump emboldens racists - \& social media empowers them. Refinery29. https://www.refinery29.com/enus/2018/10/215302/pittsburgh-shooting-reason-white-supremacists-trump

Gorcenski, E. (February 28, 2019). The Proud Boys: A Republican party street gang. Political Research Associates. http://feature.politicalresearch.org/the-proud-boys

Graham, R. (2016). Inter-ideological mingling: White extremist ideology entering the mainstream on Twitter. Sociological Spectrum, 36(1), 24-36, https://doi.org/10.1080/02732173.2015.1075927

Griffith, A. N. \& Larson, R. W. (2016). Why trust matters: How confidence in leaders transforms what adolescents gain from youth programs. Journal of Research on Adolescence, 26(4), 790-804.

Grill, J. H. \& Jenkins, R. L. (1992). The Nazis and the American South in the 1930s: A mirror image? The Journal of Southern History, 58(4), 667-694. https://doi.org/10.2307/2210789

Hand, M. (2017, October 27). White supremacists rallying in Tennessee show solidarity with Trump's immigration policies. ThinkProgress. https://archive.thinkprogress.org/white-supremacistsrallying-in-tennessee-show-solidarity-with-trumps-immigration-policies-da90b629348b/

Hankes, K., \& Amend, A. (2018, February 5). The alt-right is killing people. Southern Poverty Law Center. https://www.splcenter.org/20180205/alt-right-killing-people 
Journal of Youth Development | http://jyd.pitt.edu/ | Vol. 15 Issue 5 DOI 10.5195/jyd.2020.936 Countering Fascist Recruitment of Youth

Harbin, M. B., Thurber, A. \& Brandy, J. (2019). Teaching race, racism, and racial justice: Pedagogical principles and classroom strategies for course instructors. Race and Pedagogy Journal, 4(1), 137.

Hatewatch Staff. (2017, October 17). White nationalist flyering on American college campuses. Southern Poverty Law Center. https://www.splcenter.org/hatewatch/2017/10/17/white-nationalist-flyeringamerican-college-campuses

Helms, J. E. (1995). An update of Helm's White and people of color racial identity models. In J. G. Ponterotto, J. M. Casas, L. A. Suzuki, \& C. M. Alexander (Eds.), Handbook of Multicultural Counseling (pp. 181-198). Sage.

Horta Ribeiro, M. H., Ottoni, R., West, R., Almeida, V. A., \& Meira, W. (2019). Auditing radicalization pathways on YouTube. arXiv. https://arxiv.org/abs/1908.08313

Huang, G. C., Unger, J. B., Soto, D., Fujimoto, K., Pentz, M. A., Jordan-Marsh, M., \& Valente, T. W. (2014). Peer influences: The impact of online and offline friendship networks on adolescent smoking and alcohol use. Journal of Adolescent Health, 54(5), 508-514. https://doi.org/10.1016/j.jadohealth.2013.07.001

Jain, S., Cohen, A. K., Kawashima-Ginsberg, K., Duarte, C. D. P., \& Pope, A. (2019). Civic engagement among youth exposed to community violence: Directions for research and practice. Journal of Youth Development, 14(1), 24-47. https://doi.org/10.5195/jyd.2019.596

Jeong, S. (2018). The Internet of Garbage. The Verge. https://cdn.voxcdn.com/uploads/chorus asset/file/12599893/The_Internet of Garbage.0.pdf

Jones, S. (2017, September 7). "Antifa isn't a hobby or a fad": A Q\&A with Mark Bray. The New Republic. https://newrepublic.com/article/144723/antifa-isnt-hobby-fad-qa-mark-bray

Juodis, M., Starzomski, A., Porter, S., \& Woodworth, M. (2014). A comparison of domestic and nondomestic homicides: Further evidence for distinct dynamics and heterogeneity of domestic homicide perpetrators. Journal of Family Violence, 29, 299-313.

Kahne, J. Middaugh, E. \& Allen D. (2015). Youth, new media, and the rise of participatory politics. In D. Allen and J.S. Light (Eds.), From voice to influence: Understanding digital citizenship in a digital age (pp. 35-55). The University of Chicago Press.

Kellner, D., \& Share, J. (2007). Critical media literacy, democracy, and the reconstruction of education. In D. Macedo \& S.R. Steinberg (Eds.), Media literacy: A reader (pp. 3-23). Peter Lang Publishing.

Kendi, I. X. (2016). Stamped from the beginning: The definitive history of racist ideas in America. Bold Type Books.

Koc, M., \& Barut, E. (2016). Development and validation of new media literacy scale (NMLS) for university students. Computers in Human Behavior, 63, 834-843. https://doi.org/10.1016/j.chb.2016.06.035 
Journal of Youth Development | http://jyd.pitt.edu/ | Vol. 15 Issue 5 DOI 10.5195/jyd.2020.936 Countering Fascist Recruitment of Youth

Kruse, S. D. \& Rodela, K. C. (2019). When hate comes to campus: Campus readiness for conflict, safety, and student voice. Journal of Cases in Educational Leadership, 22(3), 85-97. https://doi.org/10.1177/1555458919860241

Kumaran, M., Fogarty, K., Terminello, A. \& Fung, W. M. (2014). The 4-H Health Rocks! Program in Florida: Outcomes on youth tobacco, alcohol, and other substance abuse prevention. Journal of Youth Development, 9(2), 65-76.

Lee, J. E., Culpepper, M., \& Julien, R. (2013). Working toward peace: A holistic approach to addressing youth violence by Pleasant Hill Baptist Church. Journal of Youth Development, 8(2), 84-95. https://doi.org/10.5195/jyd.2013.98

Leighninger, M. (2014, 2018 re-release). Infogagement: Citizenship and democracy in the age of connection. infogagement: citizenship and democracy in the age of connection (pp. 1-49). Philanthropy for Active Civic Engagement (PACE). http://www.pacefunders.org/wpcontent/uploads/2018/08/2018-Infogagement-Re-Release.pdf

Lerner, J. V., Bowers, E. P., Minor, K., Boyd, M. J., Mueller, M. K., Schmid, K. L., Napolitano, C.M, LewinBaza, S., Lerner, R. M. (2012). Positive youth development: Processes, philosophies, and programs. In R. M. Lerner, M. A. Easterbrooks, J. Mistry, \& I. B. Weiner (Eds.), Handbook of psychology, Vol 6: Developmental psychology (2 ${ }^{\text {nd }}$ ed., pp. 365-392). John Wiley \& Sons.

Lerner, R. M. (2001). Promoting promotion in the development of prevention science, Applied Developmental Science, 5(4), 254-257. https://doi.org/10.1207/S1532480XADS0504 06

Lewis, R. (2018). Alternative Influence: Broadcasting the Reactionary Right on YouTube. (pp. 1-61). Data \& Society.

Lorber, B. (2019, October 22). Taking aim at multiracial democracy. Political Research Associates. https://www.politicalresearch.org/2019/10/22/taking-aim-multiracial-democracy

Lyons, M. (2017). Ctrl-alt-delete: An antifascist report on the alternative right. Political Research Associates. https://www.politicalresearch.org/2017/01/20/ctrl-alt-delete-report-on-thealternative-right

Lyons, M. N. (2018). Insurgent Supremacists: The U.S. Far Right's Challenge to State and Empire. PM Press.

Maza, C. (2017, November 8). What to do when you accidentally book a white-supremacist band. Pacific Standard. https://psmag.com/social-justice/fighting-white-supremacist-bands

Murphy, P. P. (2019, September 25). MLS just walked back its ban of an anti-Nazi symbol at its soccer matches. CNN. https://edition.cnn.com/2019/09/25/sport/anti-nazi-mls-ban-trnd/index.html

Messner, M. A. (2016). Forks in the road of men's gender politics: Men's rights vs feminist allies. International Journal for Crime, Justice and Social Democracy, 5(2), 6-20. 
Journal of Youth Development | http://jyd.pitt.edu/ | Vol. 15 Issue 5 DOI 10.5195/jyd.2020.936 Countering Fascist Recruitment of Youth

Mihailidis, P., \& Thevenin, B. (2013). Media literacy as a core competency for engaged citizenship in participatory democracy. American Behavioral Scientist, 5711), 1611-1622. https://doi.org/10.1177/0002764213489015

Mihailidis, P., \& Viotty, S. (2017). Spreadable spectacle in digital culture: Civic expression, fake news, and the role of media literacies in "post-fact" society. American Behavioral Scientist, 61(4), 441-454. https://doi.org/10.1177/0002764217701217

Nicotera, N., \& Bassett, D. M. (2015). Building civic leadership: The journeys of pre-adolescent youth. Journal of Youth Development, 10(1), 19-33. https://doi.org/10.5195/jyd.2015.417

O'Connell, M. E., Boat, T., \& Warner, K. E. (Eds.). (2009). Preventing mental, emotional, and behavioral disorders among young people: Progress and possibilities. National Academies Press. https://www.ncbi.nlm.nih.gov/books/NBK32775/pdf/Bookshelf NBK32775.pdf

Picciolini, C. (2017). White American youth: My descent into America's most violent hate movement and how I got out. Hachette Books.

Prinstein, M. J., \& Dodge, K. A. (Eds.). (2008). Understanding peer influence in children and adolescents. Guilford Press.

Prochaska, J. O., Redding, C. A., \& Evers, K. E. (2015). The transtheoretical model and stages of change. In K. Glanz, B. K. Rimer, \& K. Viswanath (Eds.), Health behavior: Theory, research, and practice (pp. 125-148). Jossey-Bass.

Quinlan, C. (2019, August 31). How 'straight pride' parades like the one in Boston mask a far-right agenda. ThinkProgress. https://archive.thinkprogress.org/boston-straight-pride-means-more-farright-abuse-of-trans-people-a4ed06427125/

Riestenberg, N. (2008). Applying the framework: Positive youth development and restorative practices. Journal of Youth Development, 3(1), 113-122. https://doi.org/10.5195/iyd.2008.324

Riley, A. (2019). Social and emotional learning in practice: A resource review. Journal of Youth Development, 14(3), 212-216. https://doi.org/10.5195/jyd.2019.850

Ryoo, J. J., \& Kekelis, L. (2018). Reframing "failure" in making: The value of play, social relationships, and ownership. Journal of Youth Development, 13(4), 49-67. https://doi.org/10.5195/jyd.2018.624

Saleh, Z., Nakonechny, V., Denis, M. S., \& Nichols, D. (2017). BLAST: A promising approach to service, ethics, and leadership development in rural Canada. Journal of Youth Development, 12(3), 50-62. https://doi.org/10.5195/iyd.2017.451

Schaeffer, C. \& Zimmermann, F. (2019, November 8). They are racist; Some of them have guns. Inside the white supremacist group hiding in plain sight. ProPublica.

https://www.propublica.org/article/they-are-racist-some-of-them-have-guns-inside-the-whitesupremacist-group-hiding-in-plain-sight 
Journal of Youth Development | http://jyd.pitt.edu/ | Vol. 15 Issue 5 DOI 10.5195/jyd.2020.936

Countering Fascist Recruitment of Youth

Schroeder, J. [@iproposethis]. (2019, August 13). Do you have white teenage sons? Listen up. I've been watching my boys' online behavior \& noticed that social media and . . . [Tweet]. Twitter. https://twitter.com/iproposethis/status/1161130456286289920?lang=en

Smischney, T. M., Roberts, M. A., Gliske, K., Borden, L. M., \& Perkins, D. F. (2018). Developing youth competencies: The impact of program quality. Journal of Youth Development, 13(4), 29-48. https://doi.org/10.5195/jyd.2018.587

Southern Poverty Law Center. (2015, March 26). Stormfront: A history. Hatewatch. https://www.splcenter.org/hatewatch/2015/03/25/stormfront-history

Southern Poverty Law Center. (2017). White nationalists work to make inroads at U.S. colleges. Intelligence Report, 2017 Spring. https://www.splcenter.org/fighting-hate/intelligencereport/2017/white-nationalists-work-make-inroads-us-colleges

Southern Poverty Law Center. (n.d.). Male supremacy. https://www.splcenter.org/fightinghate/extremist-files/ideology/male-supremacy

Stanford History Education Group. (2016). Evaluating information: The cornerstone of civic online reasoning. (pp. 1-29). Stanford History Education Group.

Sunshine, S., Campbell, J., Rural Organizing Project, Political Research Associates, HoSang, D., Besa, S., \& Berlet, C. (2016). Up in arms: A guide to Oregon's patriot movement (pp. 1-188). Rural Organizing Project. https://rop.org/wp-content/uploads/2019/11/Up-in-Arms Report PDF.pdf

Sunshine, S. (2017). Three pillars of the alt right: White nationalism, antisemitism, and misogyny. Political Research Associates. https://www.politicalresearch.org/2017/12/04/three-pillars-of-the-alt-rightwhite-nationalism-antisemitism-and-misogyny

Sutton, M., \& Wright, C. (2009). Finding the far right online: An exploratory study of white supremacist websites. Internet Journal of Criminology, 1-24.

Thompson, A. C., Winston, A., \& BondGraham, D. (2017, October 19). Racist, violent, unpunished: $A$ White hate group's campaign of menace. ProPublica. https://www.propublica.org/article/whitehate-group-campaign-of-menace-rise-above-movement

Van Valkenburgh, S. P. (2018). Digesting the red pill: Masculinity and neoliberalism in the manosphere. Men and Masculinities, https://doi.org/1097184X18816118

Watts, R. J., Diemer, M. A., \& Voight, A. M. (2011). Critical consciousness: Current status and future directions. In C. A. Flanagan \& B. D. Christens (Eds.), Youth civic development: Work at the cutting edge. New Directions for Child and Adolescent Development, 134, 43-57.

Ward, E. K. (2017, Summer). Skin in the game: How antisemitism animates white nationalism. The Public Eye, (91), 9-15. Political Research Associates. https://www.politicalresearch.org/sites/default/files/2018-10/PE Summer2017 web.pdf 
Journal of Youth Development | http://jyd.pitt.edu/ | Vol. 15 Issue 5 DOI 10.5195/jyd.2020.936 Countering Fascist Recruitment of Youth

Yang, F., Tan, K.-A., \& Cheng, W. J. Y. (2013). The effects of connectedness on health-promoting and health-compromising behaviors in adolescents: Evidence from a statewide survey. The Journal of Primary Prevention, 35(1), 33-46. https://doi.org/10.1007/s10935-013-0327-y

Zimmer, T., Flaherty, B., Miranda, J., White, C., Juarez-Scruggs, J., \& People's Action. (2018). "No one's ever asked me before": Conversation with North Carolina's rural communities. Down Home North Carolina. https://downhomenc.org/wp-content/uploads/2018/03/dhnc-2018-report-FINAL.pdf 